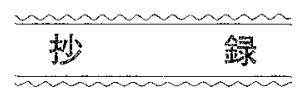

\section{一钞録 者}

原料: 岡野武雄, 藤井紀之 陶磁器 : 加藤悦三, 山本隆一 上松敏明 ガラス・玩瑯 : 境野照雄, 崖册 貫, 上松敏明 千野英春, 中村正妵, 長谷川洋, 祖川 理 セメント。 プラスター類: 赤津 健, 下田 孝, 門奈 泉 酎火物 : 大庭 宏, 滑石直幸, 林 武志, 開田高生, 上松敏明 研 磨材・研磨工具 : 伊藤昭三, 西村 暴, 花岡忠昭工程。 装置 : 田中弘文, 中村雅彦 電子钓料 : 金丸文一, 千葉 倠 基礎科学：㶯田博明，白須賀公平，高不茂栄 美術工 芸: 加藤悦三

\section{1. 原料}

Swat 粘土の害業的恎質 I: 物理的性質 II: 化学的性質 F.A. Faruqi, A. Haq, M. Ahmad and M. Aslam, Pakistan J. Sci. Ind. Res. 12 [4] 466-74 (1970).

Pipri, Feni 地方からのガラス用砂 F.A. Faruqi and M. Hanif, Pakistan J. Sci. Ind. Res. 12 [4] 479 (1970).

ラワルピンジ州 Camphellpore 地方 Bagh 付近の粘士蹠 床の鉱物学 M.A. Qaiser, M.K. Ali and Q.H. Khan, Pakistan J. Sci. Ind. Res. 12 [4] 483 (1970).

加熱顯微鏡による長石の研究 M. Obst and I. Šimon, Keram. Z. 22 [4] 209-14 (1970).

๑Vicedo カオリン: 新しいスペイン産原料 O. Brennecke, Keram. Z. 22 [6] 345-46 (1970).

Thansüsser Gottfried 巨晶花崗岩：その調製と富鉱化

A. Gottfried and K. Rehmann, Keram. Z. 22 [6] 348-50 (1970).

Petschmorgen の棌鉱ピット: Fuchs 工場の新しい露天堀 粘土堀所 E. Groll, Keram. Z. 22 [6] 350-51 (1970).

コペンハーゲン大学で得られた岩石の鉱物分離の進歩 $K e-$ ram. Z. 22 [6] 356 (1970).

○人ルウエー産浮遊選鉱カオリン R. Weiss, Keram. Z. 22 [6] 343 (1960); Interceram 19 [2] 112-14 (1970).

Zaragoza 地方産窒業原料 J.M.G. Peña and D. AlvarezEstrada, Bol. Soc. Española Cerám. 9 [2] 121 (1970).

窐業用長石の熔融特性の顕微鏡的研究 O.E. Radczewski， Ber. Deut. Keram. Ges. 47 [6] 351-57 (1970).

粘土鉱物による水の湿潤熱と吸収熱 Yu.I. Tarasevich, V.M. Rudenko, F.A. Belik and A.O. Orazmuradov, Ukrainskij Himičeskij Žurnal, [7] 680-83 (1970).

\section{2. 陶 磁 器}

施嬏両面タイルの吸水と結箱の䂰究 T. Wiedmann, Keram. Z. 22 [4] 219-20 (1970).

皿製造の新しい観点 H. Pfuhl, Keram. Z. 22 [4] 236 (1970); Interceram 19 [2] 133-35 (1970).
高賹, 高圧下の天然ステアタイトの物理, 化学的転移 $\mathrm{E}$ 。 Stoicovici, R. Cipau and Z. Gropsianu, Keram. Z. 22 [4] 216-19 (1970).

タイル製造用の最近の装喕Ｃ. Eustacchio, Keram. Z. 22 [7] 407-09 (1970).

高電圧用碍子の製造 H. Pfuhl and E. Kessel, Keram. Z. 22 [7] 410-12 (1970).

ポーセレン製造時のムライト結晶化のカイネチックス J.P. Hamon and P. Pilorget, Ceramiques Industrielles, [7] 4345 (1970).

チュニジヤの梥業 M. Fourati, Ceramiques Industrielles, [7] 57 (1970).

陶磁器体の性質への可塑性粘士の影響 D.W. Skawran and R.O. Heckroodt, Interceram 19 [2] 107-11 (1970).

エジプトの䆰業 V。サーメットの基礎的研究 M.Y. Bakr, Interceram 19 [2] 144-48 (1970).

制御されたプレス工程とその煉瓦の密度, 強度への影響

E. Schulz, Sprechsaal 103 [5] 193-202 (1970).

成形の光弾性的研究 G. Bode, Sprechsaal 103 [6] 24448 (1970).

壁，床，モザイク材のブレスと婇がけの同時完成一钣材工業 の新しい可能性 O. Friedrich, Sprechsaal 103 [8] 319-20 (1970).

プレファブパネルの損傷の研究 J. Jegou-Vilnat and M. Pusset, Bull. Soc. Franç. Céram., [87] 35-47 (1970).

セラミック製品の強度試験の統計的評価 D. Hülsenberg, Silikattechnik 20 [11]364-68 (1969).

\section{3. ガラス・㟆瑯}

ソーダ石灰ガラス表面からの熱的イオン放出 W. Bode and P.C. Fletcher, J. Appl. Phys. 40 [10] 3927-30 (1969).

$\mathrm{SiO}_{2} 68, \mathrm{Al}_{2} \mathrm{O}_{3} 3, \mathrm{~B}_{2} \mathrm{O}_{3}$ 1.5, $\mathrm{K}_{2} \mathrm{O} 0.6, \quad \mathrm{Na}_{2} \mathrm{O}$ 16, $\mathrm{CaO}$ 5.6, $\mathrm{MgO} 4, \mathrm{BaO} 2, \mathrm{SO}_{3} 0.2 \mathrm{wt} \%$ の $\mathrm{K}-6$ ガラスの細管を 電蓺線汇かぶ技，真空中で加熱して放出されるイオンを質量分 析した，陰荷電粒子としては電子だけが見此され，その放出に

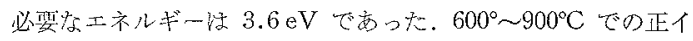
オン祇 $\mathrm{H}_{2} \mathrm{O}^{+}, \mathrm{CO}^{+}, \mathrm{CO}_{2}{ }^{+}, \mathrm{Na}^{+}, \mathrm{K}^{+}$で, $\mathrm{Na}^{0}, \mathrm{~K}^{0}$ 注い。 $\mathrm{K}^{+}$のイオン電流性 $\mathrm{Na}^{+}$の101 2 倍であり, 放出のエネル

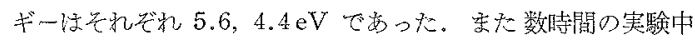
イオン電流は一定で, 再現性すよかった。通常 $\mathrm{R}_{2} \mathrm{O}$ が蒸発す るといわれているのは正しくない。図 2 , 裴 1 , 文献 8

(岸井 貫)

ポリアルキルメタクリレートのレーザーによる損傷の生畏速 度とガラス䎐移温度との関係 H. Kusakawa and K. Takahashi, J. Appl. Phys. 40 [10] 3954-58 (1969).

メチルメタクリレートとブチルメタクリレートの共重合物, エチルプロピルプチルなどのメタタリレートの各重合物な どにバナジルフタロシアニン色素省添加したものを, Qスイッ チ・レーザー用のスイッチ要素として発振器中に入れ, 発振し なくなる宋でのレーザー発振回数 $m$ 莸比べた。発振出力は 30 〜75 mJであった。 $m$ は重合物のガラス転移点 $T_{g}$ と関連が あり, $T_{g}$ が $53^{\circ} \mathrm{C}$ のもの活 1130 回, $115^{\circ} \mathrm{C}$ のものは 55 回 
で，使用温度 $\left(27^{\circ} \mathrm{C}\right)$ を $T$ とするとき， $d \log (1 / m) / d \log$ $\left(T_{g}-T\right)$ 注添ぼ $2, d \log (1 / m) / d\left(T_{g} / T\right)$ はほぼ 6 であった。 $T$ が $T_{g}$ に近いと熱伝導率が高いこと占，乙の現像の一つの 説明であるう。図 3, 表 1 , 文献 13

(岸井 貫)

開口の大きい板状ガラス・レーザー系 J.E. Swain, R.E. Kidder, K. Pettipiece, F. Rainer, E.D. Baird and B. Loth, J. Appl. Phys. 40 [10] 3973-77 (1969).

レーザーの出力エネルギーの積分值を大きくするためには， レーザーの開口を大きくする必要があるが，従来の棒形のもの では，励起㣻十分でなくなるし，レーザ一作用の市る添加物它 稀薄にする必要が市って，全出力がかえって弱められるなどの 欠点が生じる. $14 \mathrm{~cm} \phi \times 1.25 \mathrm{~cm}$ の $\mathrm{Nd}$ 添加ガラス板 5 放を， 光路とブリニースター角をなすように立位べ，励起光を円板面か ら斜めに入射させる配置をとった。この方法で，レーザー系自

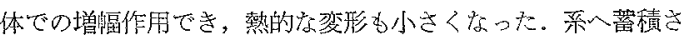
れるエネルギーは 1 枚当り $90 \sim 100 \mathrm{~J}, 1 \mathrm{~cm}^{3}$ 当り $0.6 \sim 0.7 \mathrm{~J}$ であった。15枚の系管計画している。図 9, 文献 42

(岸井 貫)

アウエルバッハの法則のエネルギー。バランスによる説明の

証拠としての，加傷されたガラスのヘルッ破壊実験 F.BLangitan and B.R. Lawn, J. Appl. Phys. 40 [10] 4009. 17 (1969).

脆い物質に球を強く押付けたときにできる截頭円錐面形のへ ルックラックの機構として, 球との接面の近くで強い張力がで き，その部分にある微小な傷（グリフィスフロウ）によって決 まる限界強度を超えたときに生じるという考党と, 接触により 生じた弾性エネルギ一は微小な破面の形成により刻々に緩和さ れるが，最後に急速な破面形成艻必要になり，この部分だけが 巨視的に検知されるという考光とがある。球の半径 $r$ と限界全

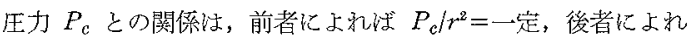
ば $P_{c} / r=$ 一定 の関係がある。また球を高い所から落す場合， クラックを生じる限界高さ $h_{c}$ は前者では一定, 後者では $r h_{c}{ }^{3 / 5}$ 二一定 の関係分むる。 \#240，320，400，600 の研削材で加傷 したガラス板について，r老 $0.08 \sim 1.9 \mathrm{~cm}$ の範囲で実験した ところ，後者の仮定による方が結果をよく説明できた．加傷し た試料ではデータのばらつきす少なく, 表面エネルギーを正確 に求める方法としても希望怔ある. 図 11, 写真 1, 文献 17

\section{(岸井 貫)}

遷移族酸化物を含むガラスの電導度の周波数依存性の原因と してのポーラロン A.P. Schmid, J. Appl. Phys. 40 [10] 4128-36 (1969).

遷移族イオンに局在している電子が㱛接した，エネルギー差 分熱振動のエネルギー $k T$ より小さいよらなイオンへ活活性 化しないでトンネル効果で移り， $k T$ より大きいエネルギー差 のある嚾接位置へは，熱的活性化を待ってポッピングで移ると 考光，エネルギー差の大または小の险接位置の存在確率の温度 依存性定考慮に入れると, 高温で注ホッと゚ングが, 低温で注卜 ンネリングが主として電導に寄与し，この移り変りの温度注印 加電圧の周波数が高い注ど高音ることが理諭的に算出され， $\mathrm{V}_{2} \mathrm{O}_{5}-\mathrm{P}_{2} \mathrm{O}_{5}$ 系ガラスの実験結果と非常によく一致した。㘝 4, 文献 12

(岸井 貫)

無定形ゲルマニゥムの比熱と結晶化熱 H.S. Chen and D.
Turnbull, J. Appl. Phys. 40 [10] 4214-15 (1969).

$10 \sim 20 \mu$ 厚に真空蒸着したものと, $\mathrm{GeCl}_{4}$ 溶液から $50 \mu$ 厚 飞電解析比したものと走査力口リメータで $200^{\circ} \sim 500^{\circ} \mathrm{K}$ で 測った. 結晶の定生比熱が $200^{\circ} \rightarrow 700^{\circ} \mathrm{K}$ で $5.1 \rightarrow 6.2 \mathrm{cal} / \mathrm{g}$ 原 子。K であるのに対し，これに比べての過剩比熱流，電解生成 物で $-0.018+10.3 \times 10^{-4} T$, 蒸着物で $-0.05+9.35 \times 10^{-4} \mathrm{~T}$ と表わされた， $200^{\circ} \mathrm{C} て ゙$ 発熱があり，結晶は析出しないが， $\mathrm{X}$ 線の小角散乱が弱拣り，構造が規則化するのを示す。 $450^{\circ} \mathrm{C}$ 以 上で $2.75 \pm 0.20 \mathrm{kcal} / \mathrm{g}$ 原子の結晶化熱で結晶化する. この值 注融解熱 $8.9 \mathrm{kcal} / \mathrm{g}$ 原子に比べて小さく, Ge が四面体的に配 位し，四面体分たがいに連結して無定形網目を作っていること を示唆する。図 2, 文献 12

(岸井 貫)

ガラスの伝熱と輻射の相互作用 G.K. Chui and R. Gardon, J. Am. Ceram. Soc. 52 [10] 548-53 (1969).

定常状態と遷移状熊で，一次元の熱移動について，その輻射 と伝導の相互作用を取报った. 新しい電子計算機のプログラム を使用して輻射と伝熱堂組合せて, 一次元の板ガラスや他の透 熱性材料を横ぎる熱フラックスを定常状態温度が, 種々の物理 的性質と境界条件によってどのよらに左存されるかを研究し た. 以前著者の検討したS型温度分布注，透熱枋料に拈いて輻 射と伝導が同時に作用するときの唯一の可能な分布ではなく， 表面温度が規定される場合に，一定な S字型温度分布になる。 表面熱移動速度分規定された境界条件の場合, 温度分布は $\mathrm{S}$ 字 型なたは逆の曲率であり，これはガラスとその周囲の間の熱フ ラックスが, 純粋に輻射か, 一部輻射, そして一部伝熱, また は対流かにより，そしてガラスが全領域に渡って透熱性である か，また一部が透熱性であるかによって左右される。輻射と伝 熱注簡単には加成的でないことがわかった。これらは, 全熱つ ラックスが最大になるような温度分布を与えるような相関過程 である，高温で注熱フラックスの輻射の部分は伝熱部分より， はるかに大きいようである。これらの割合怯材料の厚されよっ て変化する。輻射と伝熱の相互作用洼温度分布と熱フラックス に複雑に影響を与え, そして境界条件と物理的性質に低存して いる.

ガラスの熱伝導它測定する笑験の計算シュミレーション宗 し，そしてガラス製造タンクの縦の温度断面図を予想する試み を行なった。困 9 , 文献 12

(牧島亮男)

ガラスの残留応力の計算 O.S. Narayanaswamy and R. Gardon, J. Am. Ceram. Soc. 52 [10] 554-58 (1969).

Lee, Rogers, Woo ら治強化によってガラス中に発生する応 力定計算扵る理論定発表した. (J.Am. Ceram. Soc. 48 [9] 480-87 (1965)) 本報告の目的恃実験デー夕と理論の比較評価 をすることである。その結果応力分布の計算值と害験值に差異 があることが判明した，歪点以上の初期温度より急冷したガラ スの場合，この差異以理論艺れ自身の欠点でなく，理論の数式 によったすのである.この数式冠修正すると, 計算と観察した

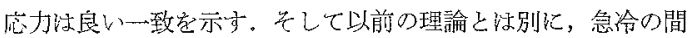
の残留応力ばかりでなく, 摡移応力もうまく予想できる。この こと法此較的高い温度より急泠し，そして熱処理した時の機械 的变化は, 熱レオロジ一的に簡単な粘弾性材料と同样の性格を 持っているとと宗ず，そして低い温度で熱処理（徐泠を含め て）したときに，ガラスを熱レオロジー的に簡単な粘弾性材料 
と規定するのは適当でない，低い初期温度より急冷すると，現 在の理論は実験データと良く一致しない。この理由は, 強化ガ ラスの構造的不均一性と残留応力によるものであるうと思われ る. 図 8 , 文献 12

(牧島亮男)

耐酸珐瑯の基礎としての $\mathbb{R}_{2} \mathbf{O}-\mathbf{A l}_{2} \mathrm{O}_{3}-\mathbf{S i O}_{2}$ 系ガラス $\mathrm{W}$. W. Wargin and W.E. Mischel, Sprechsaal 102 [24] 112528 (1969).

$20 \%$ 塩酸, $100^{\circ} \mathrm{C}, 3$ 時間加熱, ガラス粉末法で, ず $\mathrm{Li}_{2} \mathrm{O}-\mathrm{Al}_{2} \mathrm{O}_{3}-\mathrm{SiO}_{2}$ 系ガラスの酎酸度を決定して, 酎酸珐璂它 得万見地加らは，20３0 mol\% $\mathrm{Li}_{2} \mathrm{O} ， 3 \sim 9 \% \mathrm{Al}_{2} \mathrm{O}_{3} ， 65 \sim 75 \%$ $\mathrm{SiO}_{2}$ の組成領域で，重量減が $0.02 \sim 0.13 \%$ の範国となり， 市販酎酸法瑯の $0.05 \sim 0.15 \%$ と比べて, 充分実用性があるこ と学示す。

ついで $\mathrm{Na}_{2} \mathrm{O}-\mathrm{Al}_{2} \mathrm{O}_{3}-\mathrm{SiO}_{2}$ 䒺, $\mathrm{K}_{2} \mathrm{O}-\mathrm{Al}_{2} \mathrm{O}_{3}-\mathrm{SiO}_{2}$ 系ガラス についてもテストの結果, これらがいずれも $\mathrm{Li}_{2} \mathrm{O}$ 系に比心゙ て, 耐酸度分劣り, $\mathrm{K}_{2} \mathrm{O}$ 系が最低であること, $\mathrm{Li}_{2} \mathrm{O}$ 系と $\mathrm{Na}_{2} \mathrm{O}$ 系, $\mathrm{K}_{2} \mathrm{O}$ 系の混合組成のガラスは， $\mathrm{Li}_{2} \mathrm{O}$ 系ガラスに近い中間 の耐酸度をもつことを示市. これらに $\mathrm{B}_{2} \mathrm{O}_{3}, \mathrm{CaO}$ を $2 \sim 3$ mol\% 添扣して良好な工業的特性をもつ高酎酸珐唧定得飞。

さらに Sitalle と呼ばれるガラス結晶材料をうわぐすりとし て使用する立場加ら種々考察し, 得られた $\mathrm{Li}-\mathrm{K}$-Al一珪酸塩系 うわぐすりでガラス状態のものと結晶化状態のあのの耐酸性, 熱膨脹性, 耐熱衝罊性, 耐衝撃性, 硬度などを比較して, 後学 の結晶化ガラス質うわぐすりの優秀性を示守。表 2, 図 5, 写 真 2

(祖川 理)

温水タンクうわぐすりの被覆度試験Ｂ.D. Bruce and R.S. Thompson, Appliance 27 [3] 60-61, 113 (1970).

温水タンク用ガラス・コーティングの作業性の立場で, 正し い評価を下すために, Mg 陽極と珐瑯板它水中に吊して, $2.5 \mathrm{~V}$ の直流電圧を陽極にか外, 8 時間テスト後, 陽極 $\mathrm{Mg}$ 棒の重

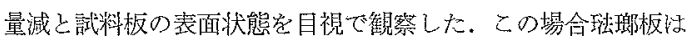
故意に薄掛し、コッパーヘッド, 焼切れ, 乾燥膜ブシシ掛けに よる露出金属面の面積と陽極 $\mathrm{Mg}$ 棒の重量減を此較した。 そ の絬果, コッパーヘッドが, 陽極腐蝕に最も有害で, 焼切れは さほど有害でないという結果が得られた。また $\mathrm{Mg}$ 陽㥛の重 量減は露出金属面積が增すにつれ增大するが，正比例はしない ことがかかった。図 1, 写真 7

(祖川 理)

伀統的珐䬶欠点の同定 D.C. Bowman, Appliance 27 [4] 75-77 (1970).

還元された鉄スケール, 鋼板中のカーバイドの偏析, 生地金 属中の介在物，うわぐすり中の金属䊀子，泡構造不良，有機物 質の混入, 鋼板中の未溶解酸化鉄, 鋳鉄の表面欠陌などの法琪 らわぐすりの欠点発生状況を顕微鏡䉼面写真で示し，可能なも のについては，父の防止策を付言する，写真 21

\section{(祖川 理)}

珐瑯掛けの前処理としての鋼の電解洗浄 W.H. Safranek and R.B. Bennett, Ceram. Ind. 94 [3] 34-35, 71 (1970).

珐瑯梓忖のための生地金属前処理工程をスピードアップする ために，他の金属表面仕上げですでに使われている超音波洗浄 や電解脱脂，酸洗，電気メッキ法の採用をす李めている，脱脂 ではこれ安でスプレー洗浄で 2 3 分かかっていたのが，陽極 脱脂で 1 分に短縮可能，タンクの壁を陰極に，バスケットを陽
極として $6 \mathrm{~V}$ の直流電压を掛訬る。脱脂困難な品物で注, 2 段 工程を取り，第 1 段階で脱脂液ガロン当り $10 \sim 20 \mathrm{~W}$ の超音波 を 1〜2 分掛け, 第 2 段階でスプレー脱脂または電解脱脂を行 なう。

酸洗での鋼板からのスケール除去に注，10〜20 W/ガロンの

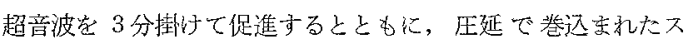
ケールや他の介在物が表面層から効果的に除去でき, さらに班 郳欠点芝誘発する水素の吸蔵が抑制される利点がある。連続又 トリップの酸洗に注 $8 \%$ 硫酸 $150^{\circ} \sim 160^{\circ} \mathrm{F}$ で $2 \mathrm{~g} / \mathrm{ft}^{2}$ の鉄を除 去するのに普通 3 分掛るところを, 陽極酸洗では $100 \mathrm{~A} / \mathrm{ft}^{2}$ の 電流密度で 1 分間に短縮できる。

さらに鉄表面符蝕のための硫酸第二鉄再生の方法, ニッタ ル，コバルト，酸化ベリリウム膜の鉄面上への電気メッキによ る形成が法瑯の付着性向上に寄与することを述べ，またアルミ 合金上への賐化クロム膜形成が電気メッキ法で，化学的コーダ ングより有效に形成できると述べる。図 1 （祖川 理）

鋼板直接珐瑯掛けのための新しい脱脂, 酸洗方法 S. Basso and E.D. Piane, Sprechsaal 103 [4] 185-87 (1970).

炭素含有量 $0.003 \%$ の極低炭素鋼板を 1 回掛订のための前処 理をするに当って, 次の迅速法を実験室的に確立した。

超音波脱脂 $50^{\circ} \sim 60^{\circ} \mathrm{C}, 3 \% \mathrm{NaOH}, 60$ 秒， $20 \mathrm{kc}$ 超音波発生 機 $\rightarrow$ 超音波水洗, 室温 60 秒 $\rightarrow$ 陽極電解酸洗硫酸 $20 \sim 25 \mathrm{~A} / \mathrm{dm}^{2}$, 60 秒 $\rightarrow$ 超音波水洗 $\rightarrow$ 電解二ッふル析出 $40^{\circ} \sim 50^{\circ} \mathrm{C}, 10 \mathrm{~g} /$ 立 $\mathrm{NiSO}_{4} \cdot 7 \mathrm{H}_{2} \mathrm{O}+2 \mathrm{~g} /$ 立 $\mathrm{NaCNS}+5.5 \mathrm{~g} /$ 立 $\mathrm{NiSO}_{4}\left(\mathrm{NH}_{4}\right)_{2} \mathrm{SO}_{4}$, $\mathrm{pH} 5.9,2 \mathrm{~A} / \mathrm{dm}^{2}$, 陰極析出 60 秒 $\rightarrow$ 水洗 $\rightarrow$ 中和 60 秒 $\rightarrow$ 乾燥 $120^{\circ} \mathrm{C}$. 写真 1 (祖川 理)

珐瑯の耐酸性と熔け易さに対する 2,3の金属酸化物の影響 N.I. Lants, Steklo i Keram. 27 [1] 28-29 (1970).

嬏薬泥浆 P. Mettke, Keram. Z, 21 [12] 798 (1969). 典型的なガラスの欠陷の原因としてのタンク炉の上部構造

J. Daudans, A. Krings and A. Sevin, Glastech. Ber. 42 [10] 391-95 (1969).

下部棈造からは酎火物が变化しないで出たもの名゙多く，筋は 稀である、上部構造から核滴，節，苶虫，筋状などのガラス， 長石，準長石類が多い。珪石棟瓦表面のガラス化した部分汃ら はクリストバライト，トリジマイトを含む滴が出，ムライト煤 瓦上を流れて溶したり粉塵を溶し込むと二次コランダム，ネフ ェリンを作る、ジルコニヤコランダム質搷瓦と反応したとき は, 二次ジルコニヤも出し，ガラス相は煉瓦中のそれと類似し てくる。これらの鉱物とガラスは，ガラス中に溶けにくく危険

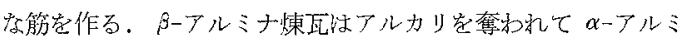
ナに変り，收繀し侵蝕される。滴梳コランダム粒を含んだ石に なる。欠陷が製品に多く出たら，先入観なしに多数の試料をと り，双眼顕微鏡で分類し，不透明のもの注薄くし，形を見る。 上部構造からの6のは変態していることが多く, 原因となった 棟瓦固有の鉱物は見つ讨難い. $\mathrm{Ti}, \mathrm{V}, \mathrm{Zr}, \mathrm{Fe}$ の含量も調心゙ る. 対策として, 滴はガラス中で溶解させる。粉塺の飛散をな くし，そのため必要なら炎の形，向き考变える。バッチに水分 を添加したり，装入法を検討する。これらの方法がだめなら溶 解さ过る。電気ブースティング，バブリング，炉温分布翌更な ぞの対策をとる。特定棟瓦に起因する場合惊，十分に確認して 交換する. 図 1, 写真 10 , 表 1 , 文献 7 （岸井 貫） 
潜望鏡を用いたガラスタンク炉の炉室の写真撮影とフィルム H.J. Voss and W. Mergler, Glastech. Ber. 42 [10] 396405 (1969).

目的により潜望鏡の視野躴点距離 $90 \mathrm{~mm}$ のレンズで $90 \times$ $60 \mathrm{~mm}$ フィルム写したり，25 mm でシネマ纪しりする必 要があり，露出も長くてよいときと，炎笔 1/1000 秒でとりた

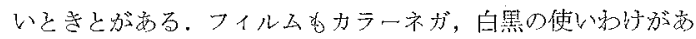
り，これらの組合わせに対しての最適条件定経駼的に定方表示 した。潜望鏡の保護ガラスと刘物レンズとを乾燥して, 油分を 含まないがスで泠却，防麾状態保つととが大切である。視野 が広く，広範围を先端の回転だけで簡単にカバーできる。天 井, バーナ開口, 炎, バッチ, バブリング泡, シャドウ・ウォ 一ル，格子などを撮影した例を揭げた。写真 15 , 表 2

（岸井 買）

㘿堝炉の寿命とガラス品質への燃焼の意義 D. Starzinsky, Glastech. Ber. 42 [10] 405-09 (1969).

煤埫に䁆裂を作ると侵蝕が進み，ガラスの品質が悪くなる。 浮翰学坩城中に，底から支持体学使ってはなして入れ，㘿城の

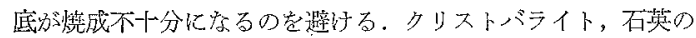
転移温度域をとくにゆっくり通過するように，1週間加けて

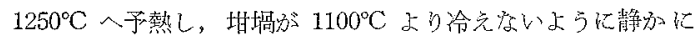
熔融和八移寸。予熱炉，熔融虭とも正圧として冷気進入儿よる 重裂を防ぐ，運搬具との接触による龟裂にも注意する。燃焼が

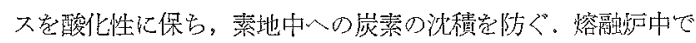

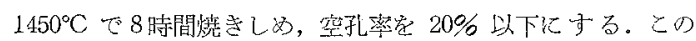
時坩堝の開口と底との温庋差は $20^{\circ} \mathrm{C}$ 以下, 天井との温度差

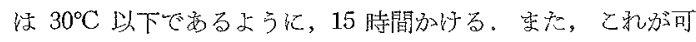
能なように設計や操業から注意が必要である。坩堝に鼻裂が生 じると，侵蝕が焦み，必ず製品步留りが顕著倍落ちる。原料装 入前に, 坻堝内面にガラスがけし, 冷気, 原料, 炎により黾裂

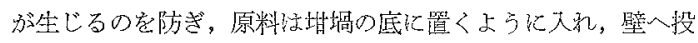
ゲつけるのを避计当。図2, 写真 6

(岸茾 贔)

ガラス用タンク炉の熱工学的特性 III. 熔融率向上と熱消 費量への電文補助加熱の影響 W. Trier and H.J. Voss, Glastech. Ber. 42 [10] 409-18 (1969).

炎からの熱柱バッチ上面と清澄域のガラス浴中とへ伝わり，

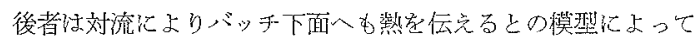
特性它計算してきた。本報ではさらに浴中で電打よるる熱量が

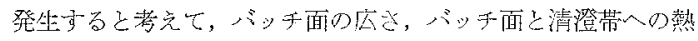
の配分学, 全入熱量, 電力量など岂パラメ一タとして, 引上量 増加 $1 \mathrm{~kg}$ 当りの熱消費壘索計算し, 図示した。図 5 , 文献 2

(岸井 賁)

引出しまたは引上法による板ガラス中に窠結された光学的非

等方性 L. Merker, Glastech. Ber. 42 [10] 419-24 (1969).

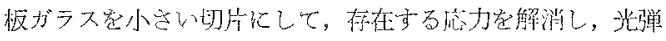
性效果による複届折を消しても, 成形時に引張りを受けなから 固化したことに起因寸る凍結された複風折が残留する。複属折 による光路差は, 固化時に受忖た応力に比例守る、リビ一・亦 一エン大法, ピッツバーグ淩, フルコール法, フロート法の各 ガラスの板幅に沿う残留光路差の分布はそれぞれ異なること管 認めた。フルコール・ガラスは此較的小さい。つぎに SiO 75, $\mathrm{Na}_{2} \mathrm{O}, \mathrm{K}_{2} \mathrm{O}$ \&な $\mathrm{Cs}_{2} \mathrm{O}$ 15, フルカリ土類酸化物 $10 \mathrm{~mol} \%$
の試験ガラスに $500^{\circ} \mathrm{C}$ で加重冷却したとと, あるいは $800^{\circ} \mathrm{C}$ て 1/1000 伸ばしたととによる光路差定測定した。 $\mathrm{Na}_{2} \mathrm{O}$ を含 すガラスでは， $\mathrm{Mg}-\mathrm{Ca}-\mathrm{Sr}-\mathrm{Ba}$ の柔列で $\mathrm{Ca}$ 亿極小があり，Ba $>\mathrm{Sr}>\mathrm{Mg}>\mathrm{Ca}$ の順になる， $\mathrm{K}_{2} \mathrm{O}$ のガラスであ同様だが， 極小注顕著でない，構成イオンの分極率などと關連させようと したが，十分ではない。図 6, 表 4, 文献 12 (岸井 貫)

\section{冬の管 : 大きい空面積が室内環境へ及ぼす熱的作用の評価}

H. Künzel, Glastech. Ber. 42 [10] 428-32 (1969).

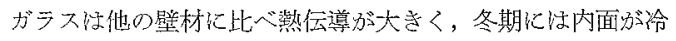
えて露学付け，严るい性冷気学発生するので，一重ガラスでは 外壁の面積の $10 \sim 20 \%$ ，二重ガラスでは 25〜 50\%をでしか使 充いとされている。乙れらの特性はガラスの表面熱伝達率が 外面で 20 , 内面で $7 \mathrm{kcal} / \mathrm{m}^{2} \cdot \mathrm{h} \cdot{ }^{\circ} \mathrm{C}$ でるとして綪度よく計算 できる、しかし実際恬，広、空の下側认はラジェ一夕学配置す ることが多いので, 内面でも龿伝達率が $20 \mathrm{kcal} / \mathrm{m}^{2} \cdot \mathrm{h} \cdot{ }^{\circ} \mathrm{C}$ に増 すと同㭙に, 内面温度も計算值より数度高まる。内外面の㪇伝 達率觉パラメータとした温度, 熱損失の図を作った。宋た空へ 入射する日光エネルギーによる空温上昇計算した，ガラス層 数功多いと上昇が小さく, $500 \mathrm{kcal} / \mathrm{m}^{2} \cdot \mathrm{h} \cdot{ }^{\circ} \mathrm{C}$ の入射で上る。 各懼の入射笨件下での熱エネルギーの得失子図示した。岁る大

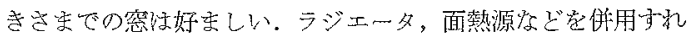
ば, 空面䅡壮上限なしに大きくしてよい。四 6, 表 2 , 文献 5

(岸并 貫)

“J.K.G. Jacobssons 技術辞典”（1781～1795) でのガラス 炉の記述 G. Stein, Glastech. Ber. 42 [10] 432-39 (1969). 18 愔紀に入ると, 各国の重商主義, 自給自足主義と関連し て, 合理的な基檚に立つ「技術」という概念が，学問から独立 し始わた。たとえね゙ゲッチンダン大学絰済学教授 J. Beckmann がこの概念它 1772 年に確立した。彼仼との辞典に序文を寄子 ている、レオミュール，ディドロ，ダランベール，ㄴと絸く多 種の百科辞典（1761～1782）の系列に属するとす見ることがで きる、ヤコブソンは「プロシヤ工業検査官」で初わの 4 巻を発 行し, 全巻の計西定残した. 彼の死後 G.E. Rosenthal が残り 4 巻完発行し, 最終巻汇泩充実した文献集があった。ローゼン タールは「ザクセンーゴタイス鉱山委員」で晾り，多くのアガデ ミ一や学会にも属していた，直接のガラス関係惊 108 項目が収 録されていて，現在加ら見ると技術史，文化史的洒值肪高く， 19 世紀になっても声洒省保持していた。 その内容の一部老 4 ページにわたり再録してある。注文者の中に注君主, 王族, 高 官, アカデミ一, 学会, 学識者, 医師, 鉱山経営者, 図書館を 始め, 多くの人があり, ゲーテも名を連祖ていて, 社会的に影 響が大きかったと推測される。文献 4 (岸州 貫)

フルコール法による板ガラスの機械による引上げの 50 年 : エミール・フルコールの 50 周忌に際して H. Goerk, Glastech. Ber. 42 [10] 448-51 (1969).

1919 年は板ガラスが口吹きから機械引!上式に翌った転機で 㐫った(それなで口吹き定機械吹き化するようになってはいた が).Vallinの 1871 年の特許で直接引法の案住方ったが, 実現が非常に難かしかった。フルコール㤬第くべき実行力と忍 耐で達成した。 1902 年に最初のフランス特許をとり，1910 年 には $4 \mathrm{~mm}$ 悬の製品定国際板ガラス連合に提比して, 開発の 筫金岩求めた。ドイッ,オーストリヤ，ボヘミヤの製造会社グ 
ループが興味を宗し，1912 年にこれらと共に Dampreny 社 を設立し，また特許保持のためフルコール社を各国作った。 ダソプレミ沈 $1 \mathrm{~m}$ 幅の引上機 8 基を持ら 1914 年初頭操業を 始めたが，秋には大戦のため休止した。 1916 年にベルギーの 被占領地で再開し，ベルギ一の解放まで続いた。戦後, 対敵劦 力者乞して报かわれ，罰放汢されたが健康を著しく害し，1919 年 10 月 11 日死去した。 20 年代にはドイッ(ザール，ヴィテ ソ,ラインなど)，ボへミヤ(ズデーテン，ゼッテンッウン テルライとェナウなど)，イギリス，アメリカなどへ搪がった。 板ガラスの生産性は飛躍的に増し，職工は不健康な作業から解 放された。現在板ガラスの半分以上， $4 \times 10^{8} \mathrm{~m}^{2} /$ 年がフルコー 儿法で作られる。彼㳉るい性格で，技術上の問題については 意見の交換につとめるのが常であった。写真 3 , 文献 10

\section{(岸井 貫)}

\section{家庭用皿洗機中でできたガラス表面の傷の落射照明式電子顯} 微鏡写真 W. Trier and H.E. Schwiete, Glastech. Ber. 42 [10] 424-27 (1969).

結晶化ガラスの形成からみたガラスの構造について W. Hinz and J. Mitsh, Silikattechnik 20 [10] 332-33 (1969). ガラスの構造と，結晶化機構との関連定 $\mathrm{K}_{2} \mathrm{O}-\mathrm{Al}_{2} \mathrm{O}_{3}-\mathrm{ZnO}$ $\mathrm{SiO}_{2}$ 系ガラスの結晶化の面から検討した。この㿟から $\mathrm{Zn}_{2} \mathrm{SiO}_{4}$ 結晶为晶出する機構の特陆を，今まで知られている制御された

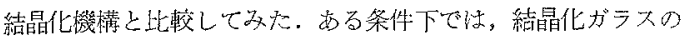
形成はガラス内部のホモジニフスな核㔙成によって始をると想 像される。この場合, 最初に析出する結晶の满造と, ガラスの 組成並びに構造との間に注高い類似性が存在すると考光られ 万。図 3 , 文献 3

(浅井孝夫)

光学ガラスの熱屈折率の変化に関する解秎について $\mathrm{H}$. Besen, Silikattechnik 20 [10] 334-37 (1969).

ガラス管の外径測定器Ｈ. Martin, Silikattechnik 20 [10] 338-39 (1969).

ダンナー法とシューラー法で製造されるガラス管の外径を， 非接触で連続的に測定する装置について述べている。この装置 の原理性，ガラス管に平行光線を斿てた時飞生じる影像它追跡 システムで走查するものであって，測定範国它 10〜100 mm と $40 \sim 200 \mathrm{~mm}$ (いずれもガラス管外径) の2段に切り換党ら 却る。

測定誤差位 $0.2 \mathrm{~mm}$ 以下，感度性 $0.1 \mathrm{~mm}$ 以下で尔可. 装

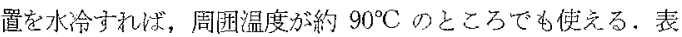
1, 図 5

(浅井菱夫)

ガラス素地面の発泡プロセスに対する熔融部の圧力変動の影

響 N.A. Pankova and L.Ja. Levitin, Steklo i Keram. 26 [10] 7-9 (1969).

恓内压於高李ると泡切線後方で素地面が泡立つことがあ が，これ惊内压上萃によって素地泡の浮上速度が低下したた めでもなく，浮上した気泡の破裂が妨げられるためでもない。

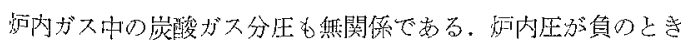

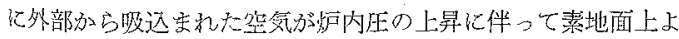
り押しのけられて素地表面層温度汃高守り， $\mathrm{CO}_{2}$ や $\mathrm{SO}_{2}$ 芝発 生する反忘の平衡がずれてこれらのガスが発生するのが原因で

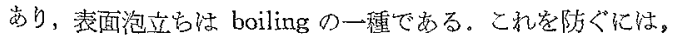
外内圧をるずかにプラスに保ち，熔融部で素地に充分の熱を与

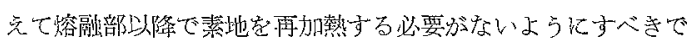
要る。図2, 文献 4 (上松敏明)

ガラスの密度の測定 E.I. Smirnov, Steklo i Keram. 26 [10] 9-11 (1969).

板ガラ大幅方向で等間隔に 10 個の試片を切り出し，重液に 入れて試片の沈を温度 $t$ に上って密度を測定する場合， $t$ のば

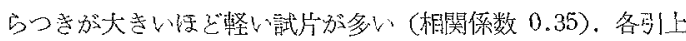
機ごとに密度索測定すれぱ hot spotを通過する軽い素地の槽 䠶輻方向の分布を知ること加でき隣接する引上機上で密度を測 定すれば一方の引上機が他方の引上機に素地流が方向完変光た 時点をチェックでき，引上げ停止や再開時に素地がごのように 流れるか子知り得る。密度の実測值 $\gamma_{0}$ とバッチ組成による計 算値 $\gamma_{c}$ の差法消費熱量が大きくなると増大する。 24 時間ごと に測定した $\gamma_{\theta}$ の变動 $\alpha^{2}$ のちちバッ千組成の変動によるもの は $20 \%$ で，80\%はバッ千組成以外の熔融条件の変動による が， $\gamma_{\theta}$ の 5 日ごとの平均值の変動怔 85〜90\%がバッチ組成の 变動による。図 2, 文献 2

(上松敏明)

強化ガラスの熱膨脹, 密度と熱経歷との関係 I.A. Boguslavskij, O.I. Puhlik and O.N. Halizeva, Steklo i Keram. 26 [10] 12-15 (1969).

F 式引上ガラスその他合計 10 锤のガラスを空冷ならびにポ リオルガノシロキサン液中液冷によって強化し, 強化前後で熱 膨脹曲線を描き, 密度を測定した。強化前後の徐冷温度域付 ける伸び率の差の最大值 $\Delta l_{\max } / l$ と転移温度以上と以下に扔计 る線膨脹保数の差 $\beta_{2}-\beta_{1}=4 \beta$ の関係住強化時の泠却速度が定であれば，ガラスの種類と関係なく直線で表わされる。強化 ガラ大の内部構造緩和開始温度 (体積縮少開始温度) $T$ と強 化時の異常膨脹区間冷却速度の対数 $\log v$ の関係法各ガラスご とに直線で表わされ $v$ が大きい济ど $T$ は低い。強化前後の密 度の差の最大值 $\Delta \delta$ と $\log v$ の関係も直線で表わされる。徐冷 ガラスの密度を $\delta_{0}$, ある基準速度で加熱した時の転移点を $T_{g 0}$, 強化ガラスの㲦移点桪多方向の平均定 $\bar{T}_{g}$ とすると, $\Delta \delta=3 \delta_{0} \frac{\Delta l_{\max }}{l}, \Delta \delta / \delta_{0}=3 \Delta \beta\left(T_{g_{0}}-\bar{T}_{g}\right)$ が成立与る。後者 の式で $\bar{T}_{g}$ の代りに強化ガラスの転移点の分布学表わす式 $T_{g}$ (X) 学代入す机ば $\Delta \delta(\mathrm{X})$ を知ることができる。後者の式は密 度以外の棒造敏感性の性質についても成立するはずである。丧 1 , 図 6 , 文献 11

(上松敏明)

ガラス・ステープル・マイクロファイバーの成形に刘するガ ス流のパラメータの影響 N.G. Karahanidi and Ja.A. Śkol'nikov, Steklo i Keram. 26 [10] 18-20 (1969).

長さ $40 \mathrm{~mm}$, 幅 $2 \mathrm{~mm}$ のスリット 2 個からプロパンプタン 混合ガス学噴出ざせ, 両者の閒の角度 $\theta$ 学 $10^{\circ}$ とし空気過剩 係数 $\alpha$. $0.83 \sim 1.20$ の間で变光, スリット出口加ら $5 \mathrm{~mm}$ 間隔で火资中心線上の温度と玨力学測金し，スリット出口から

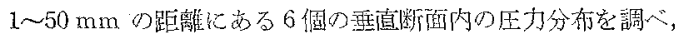
フルカリガラスの直径 $90 \sim 93 \mu$ のフラメントに $\theta=2 \sim 10^{\circ}$ で火炎を吹きつ，得られたマイクロファイバーの直径 $\alpha f$ 之 $\theta, \alpha$ の関係老淍べた。 $\theta=2^{\circ}$ と $8^{\circ}, \alpha=0.9 \sim 1.1$ で $\alpha f$ 怯 $0.25 \sim 0.3 \mu$ kなる。. 辡 1 , 図 4 , 文献 4 (上松敏明)

板ガラス生産計画に対する経済数学的方法とコンピュータ利 用の可能性 N.V. Paenson and G.F. Kalinina, Steklo $i$ Keram. 26 [10] 36-39 (1969). 
1969 年末現在で稼動中の板ガラス工場は 32 である。このう ち敷地の余裕, 原料, 燃料人手の点で拡張可能な工場恃 16 岁 る.これに 1970 年以降の新設工場立地点 21 字加党, 拡張は 一丞列年産 1550 万 $\mathrm{m}^{2}$, む乙くは 1160 万 $\mathrm{m}^{2}$, 新設能力性 1550 万 $\mathrm{m}^{2}$, むしくは 2 系列 3100 万 $\mathrm{m}^{2}$ そし, 1980 年までの 板ガラス全需要量 (三全生産量) を計算して, バッチは将来, バッチセンター方ら輸送されるはずなので, $2 \mathrm{~mm}$ 板 $1 \mathrm{~m}^{2}$ 当 りの原料量注全工場一律と仮定し， $i$ 工場が $j$ 消費地（州。 共和国の首都と仮定）飞， $X_{i j}$ の板ガラス它翰送するときの翰 送量の全工場についての総計と製造費の総計の和堂極小にする よら尔翰送量 $X_{i j}$ と製造量を電子計算機で見いだした。計算 によると 1975 年まで注欧ソの若干の工場它搪張声机ばよく, ウラル以東の工場の拡張または新設は国民経済的に不利であ る. 1980 年までには欧りに拡張の余地がなくなり，欧ソの製品 注ほぼ欧ソで消費されるので中央アジアの一工場を拡張し，シ ベリアのノボアルタイスク市に 1550 万 $\mathrm{m}^{2}$ の能力安新設する 必要肪るる。

(上松敏明)

新しい押型ガラス E.G. Račuk, Steklo i Keram. 26 [10] 44-45 (1969).

第 5 回全ソガラス相会議 O.K. Botvinkin and M.S. Aslanova, Steklo i Keram. 26 [10] 43-44 (1969).

装飾付色ガラス・ブロックの製造 O.I. Andreeva and L.I. Sankova, Steklo i Keram. 26 [10] 40 (1969).

$\mathbf{R}_{2} \mathrm{O}-\mathrm{Al}_{2} \mathrm{O}_{3}-\mathrm{SiO}_{2}$ 系ガラスを基にした化学的耐久性の大きい ガラス珐瑯と結晶化珪瑯 V.V. Vargin and V.E. Mišel', Steklo i Keram. 26 [10] 20-23 (1969).

鋼板直接珐瑯掛けのための新しい脱脂, 酸洗法 S. Basso and E.D. Piane, Sprechsaal 103 [4] 185-87 (1970).

炭素含有量 $0.003 \%$ の鋼板で, 脱脂には $3 \%$ の菏性ソーダ 浴 $50^{\circ} \sim 60^{\circ} \mathrm{C}$, 超音波 $10 \sim 100 \mathrm{kHz}$ 当加て 60 秒, 室温て 60 秒水洗後, 硫酸陽極法で $20 \sim 25 \mathrm{~A} / \mathrm{dm}^{2}$ で 60 秒電解酸洗 超音波水洗後 $10 \mathrm{~g} / l$ の $\mathrm{NiSO}_{4} \cdot 7 \mathrm{H}_{2} \mathrm{O}, 2 \mathrm{~g} / l$ の $\mathrm{NaCNS}, 5.5$ $\mathrm{g} / l \mathrm{NiSO}_{4}\left(\mathrm{NH}_{4}\right)_{2} \cdot \mathrm{SO}_{4}, \mathrm{pH} 5.9, \quad 40^{\circ} \sim 50^{\circ} \mathrm{C}$ で $2 \mathrm{~A} / \mathrm{dm}^{2}$ の 電流密度で 60 秒電解ニッケルを陰極析出, ついで水洗, 中和 そいう各工程を 1 分で処理できる前処理法が実験空的に開発さ れた。

(祖川 理)

Porcelain Metall社の完璧な珐瑯掛け Appliance 27 [5] 66-68 (1970).

アメリカのケンタッキー州のルイズビルにある Porcelain Metals 社泣ンジ, 皿洗機, ドライヤー, スペースヒーター, 熱交換器, シャワーの床, 衛生用品, 法加り, 温水器, その他 部品の珐瑯掛讨定行なっている工場で, 現在使用中の静電施婇 装置で $85 \%$ の施婇效率が得られていること, ミル設僃, スリ ップタンクの重量測定による施婇量管理, 実験室設備, $90 \mathrm{ft}$ 畏 の直線型焼成佽などが紹介されている。とくに変っているのは 忓マッフル内の温度变化に応して, 一定の熱量加いる品物に 加るるように，1個のSCR 制御直流モーターで, 焼成コンべ ヤー・チェーン学歌動していることでるる。写真 7

$$
\text { (祖川 理) }
$$

Maytag は珐瑯工場拡張 Appliance 27 [8]55-56 (1970). フメリカのアイオフ州ニュートンの Maytag 社は最近第2工 場を完成. $60,000 \mathrm{ft}^{2}$ から $110,000 \mathrm{ft}^{2}$ に拡張した。これは家
庭用洗濯機, ポータブル洗濯コニットと皿洗機の将来の需要拡 大に答光るためである。平板類忏下婇も上婇すすべて静電施 橎, プレス成形品はフローコート。14,000 ft の仕掛讨品スト ックコンベヤー定持ら, 阬はガス焚Uタイプ, ラジアントチュ ーブ式である. 写真 6

(祖川 理)

イギリス珪瑯工業 G. Clarke, J. Brit. Ceram. Sec. 7 [3] 93-96 (1970).

イギリスでは現在フリット会社約 12 ，珐瑯工場約 80 , その 中で大きいの注家庭用機器の数社である。ほとんどのバスタ プ，クッカーが珪瑡掛けされていて, 目下器物市場が好況, テ 一プルトップや流しはステンレススチールに移行中、法瑯の定 義, 歴史, 製法, 性質, 特長が紹介されている。琺瑯の新分野 としてほ, 建築珪瑯, 酎熱珐瑯, 耐水珐瑯などの使用例が挙げ れら, 直接 1 回掛讨は，いくつかのクッカーメーカーで 100\% 切り換觉に成功したと述ベられている。

(祖川 理)

アルミ珪瑯での 20 年の経験 M. McGinnis, Ceram. Ind. 94 [5] 29-30 (1969).

アルミ珐瑯の特長牥カラフルなところにあるが，一般にパス テル調の半光沢嬏が耐久性が良好で，ついで中間調の半光沢 釉，他万濃色の光沢婇では短期間にかなり变化を受けることが

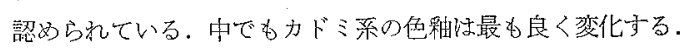
モ一ス硬度 5 . スポーリング防止には密着家良くし，婇を薄掛 けする。 $515^{\circ} \mathrm{C}$ で面耐性がある. MIG または TIG 熔接で,

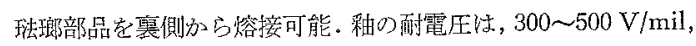
珐瑯掛讨飞適した合金法 1100，3003，6061，7104。鋳物は 43, 356, 344 などのパーマネントモールドか砂型鋳物。ダイキャ ス卜には珪瑯掛けができない。写真 4 (祖川 理)

燃焼ガス雾国気中で珐瑯焼成可能 B.W. King, Jr., C.J. Koenig and L.S. Cook, Ceram. Ind. 94 [4] 80-81, 104 (1969).

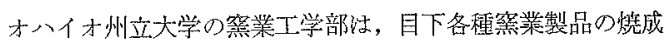
に対する恼雾囲気の影響を研究中で, 珐理の場合, 脱炭鋼上に は 20 容量％までの水蒸気を含它雾围気中でも, ガス発生に よる欠点がなく焼成でき，また $3 \sim 4 \%$ の水蒸気が存在した方 が, 乾燥空気中で焼成するより良好な表面染得られることを認 わた，次に天然がス燃焼雾囲気中では，要る程度過剩空気が存 在するならば，脱炭鋼上でも，あらかでめ下釉定掛けた板上で む良い絬果㣻得られ，過剩空気がないとチタン勫は発色が黑ず

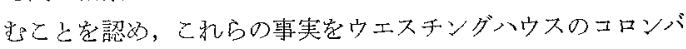
ス工場の協力学得て, 実製品で確かめている。表 1 , 写真 5

(祖)门理)

照和 45 年 12 月 25 日 印刷 炤和 46 年 1 月 1 日 発行

\section{(C)}

稻集発行者富田三郎印刷者大沼正吉 印 刷 所 107 東京都港区赤坂 1-3-6 株式会社 技 報 堂 発 行 所 160 東京都新宿区百人哃 $3-334$

$$
\begin{aligned}
& \text { 社团 㸃 業 協 会 } \\
& \text { 法人話 東京 (362) } 5231 \text { (代) } \\
& \text { 振替眝金口磨 東京 } 21133 \text { 番 }
\end{aligned}
$$

